\title{
Thermodynamic Modeling of Hanford Waste Tank 241-AN-107
}

AR Felmy

September 2005

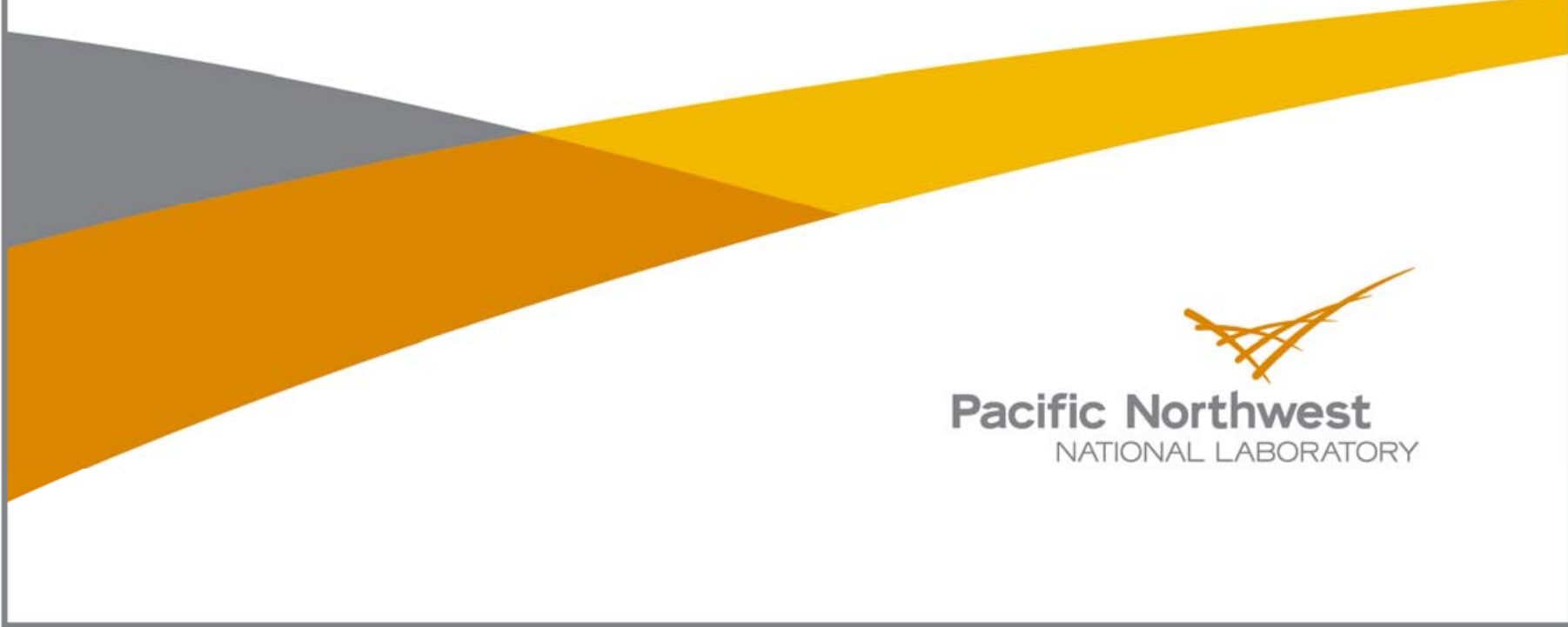




\title{
DISCLAIMER
}

This report was prepared as an account of work sponsored by an agency of the United States Government. Neither the United States Government nor any agency thereof, nor Battelle Memorial Institute, nor any of their employees, makes any warranty, express or implied, or assumes any legal liability or responsibility for the accuracy, completeness, or usefulness of any information, apparatus, product, or process disclosed, or represents that its use would not infringe privately owned rights. Reference herein to any specific commercial product, process, or service by trade name, trademark, manufacturer, or otherwise does not necessarily constitute or imply its endorsement, recommendation, or favoring by the United States Government or any agency thereof, or Battelle Memorial Institute. The views and opinions of authors expressed herein do not necessarily state or reflect those of the United States Government or any agency thereof.

\author{
PACIFIC NORTHWEST NATIONAL LABORATORY \\ operated by \\ BATTELLE \\ for the \\ UNITED STATES DEPARTMENT OF ENERGY \\ under Contract DE-AC05-76RL01830
}

Printed in the United States of America

Available to DOE and DOE contractors from the

Office of Scientific and Technical Information,

P.O. Box 62, Oak Ridge, TN 37831-0062;

ph: (865) 576-8401

fax: $(865) 576-5728$

email: reports@adonis.osti.gov

\footnotetext{
Available to the public from the National Technical Information Service, U.S. Department of Commerce, 5285 Port Royal Rd., Springfield, VA 22161 ph: (800) 553-6847 fax: $(703) 605-6900$

email: orders@ntis.fedworld.gov

online ordering: http://www.ntis.gov/ordering.htm
}

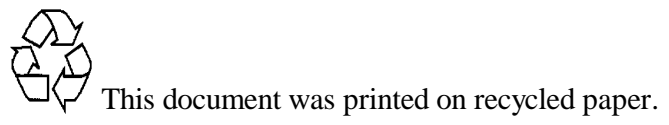


PNNL-15351

\section{Letter Report}

\section{Thermodynamic Modeling of Hanford Waste Tank 241-AN-107}

Andrew R. Felmy

September 7, 2005 
Prepared for

the U.S. Department of Energy

under Contract DE-AC06-76RL01830

Pacific Northwest National Laboratory

Richland, WA 99352 


\section{Introduction.}

The high level waste storage double-shell tanks at the Hanford site are highly basic. The high basicity is a key factor in controlling the chemical behavior of different components of the waste and in influencing the corrosion rate of the carbon steel primary tanks. However, the introduction of atmospheric $\mathrm{CO}_{2}$ can reduce the $\mathrm{pH}$ of the tank wastes over time and possibly alter the corrosion rate of the carbon steel tanks. In order to at least partially address this issue for waste tank 241-AN-107, thermodynamic modeling calculations were performed to predict the changes in $\mathrm{pH}$ and carbonate concentration that could occur as $\mathrm{CO}_{2}$ is absorbed from the atmosphere. The calculations were extended to complete equilibrium with the partial pressure of $\mathrm{CO}_{2}$ in the atmosphere (i.e. $\mathrm{pCO}_{2}=$ $\left.10^{-3.5} \mathrm{~atm}\right)$.

Simulations were performed for both the "upper" segments of tank 241-AN-107, which have been influenced by the introduction of high concentrations of $\mathrm{NaOH}$ to the supernatant, and for the "lower" segments where the salt cake/interstitial liquid have not been substantially altered by the introduction of base concentration.

\section{Thermodynamic Modeling}

Two different thermodynamic models were used in the simulations, the Environmental Simulation program ESP model (OLI Systems Inc) which uses the Bromley-Zematis equations for the activity coefficients, and the GMIN thermodynamic model ${ }^{(1)}$ which is equivalent to the Pitzer Version of $\operatorname{ESP}^{(2)}$. The thermodynamic database supporting the use of the Pitzer equations has been extensively tested and validated ${ }^{(3-12)}$ including highly concentrated carbonate solutions. Examples of the accuracy of the model for carbonate containing systems are given in Figures 1-3. Figure 1 shows an extensive comparison of the model predictions with experimental mineral solubilities for binary (two electrolyte) systems containing carbonate and bicarbonate system. Figure 2 shows comparisons of the model predictions with the more complex ternary (three electrolyte) systems and Figure 3 of the complex reciprocal $\mathrm{Na}-\mathrm{K}-\mathrm{HCO}_{3}-\mathrm{CO}_{3}-\mathrm{H}_{2} \mathrm{O}$ system. In particular the agreement of the model with the solubility data for trona shown in Figure 1c, Figure 2c,d and Figure 3 are noteworthy since as we will show, trona is a potentially important mineral phase that can form in Tank 241-AN-107. 

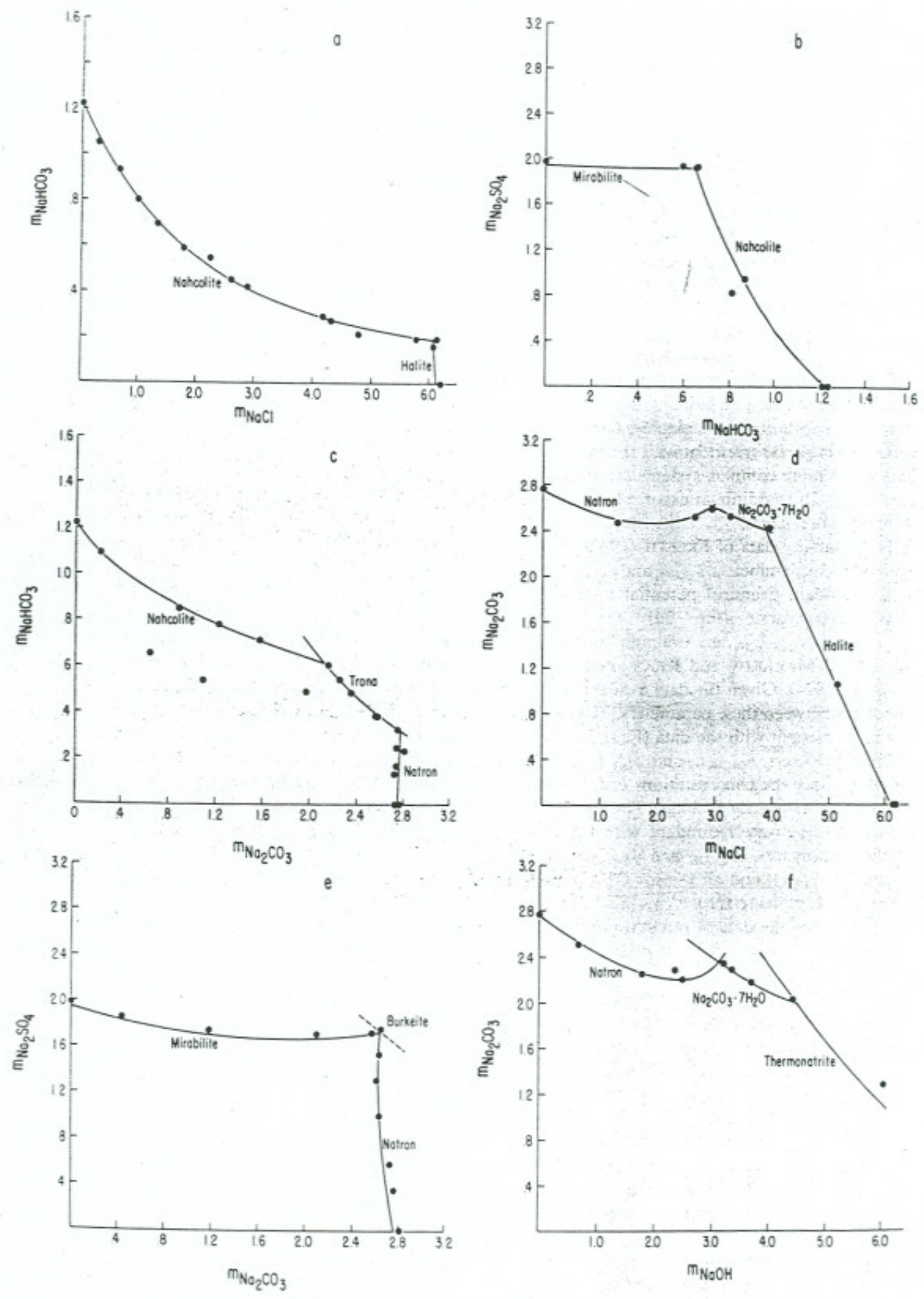

Figure 1. Mineral solubilities in the $\mathrm{Na}-\mathrm{Cl}-\mathrm{SO}_{4}-\mathrm{HCO}_{3}-\mathrm{CO}_{3}-\mathrm{OH}-\mathrm{H}_{2} \mathrm{O}$ system (from Harvie et al. 1984). 

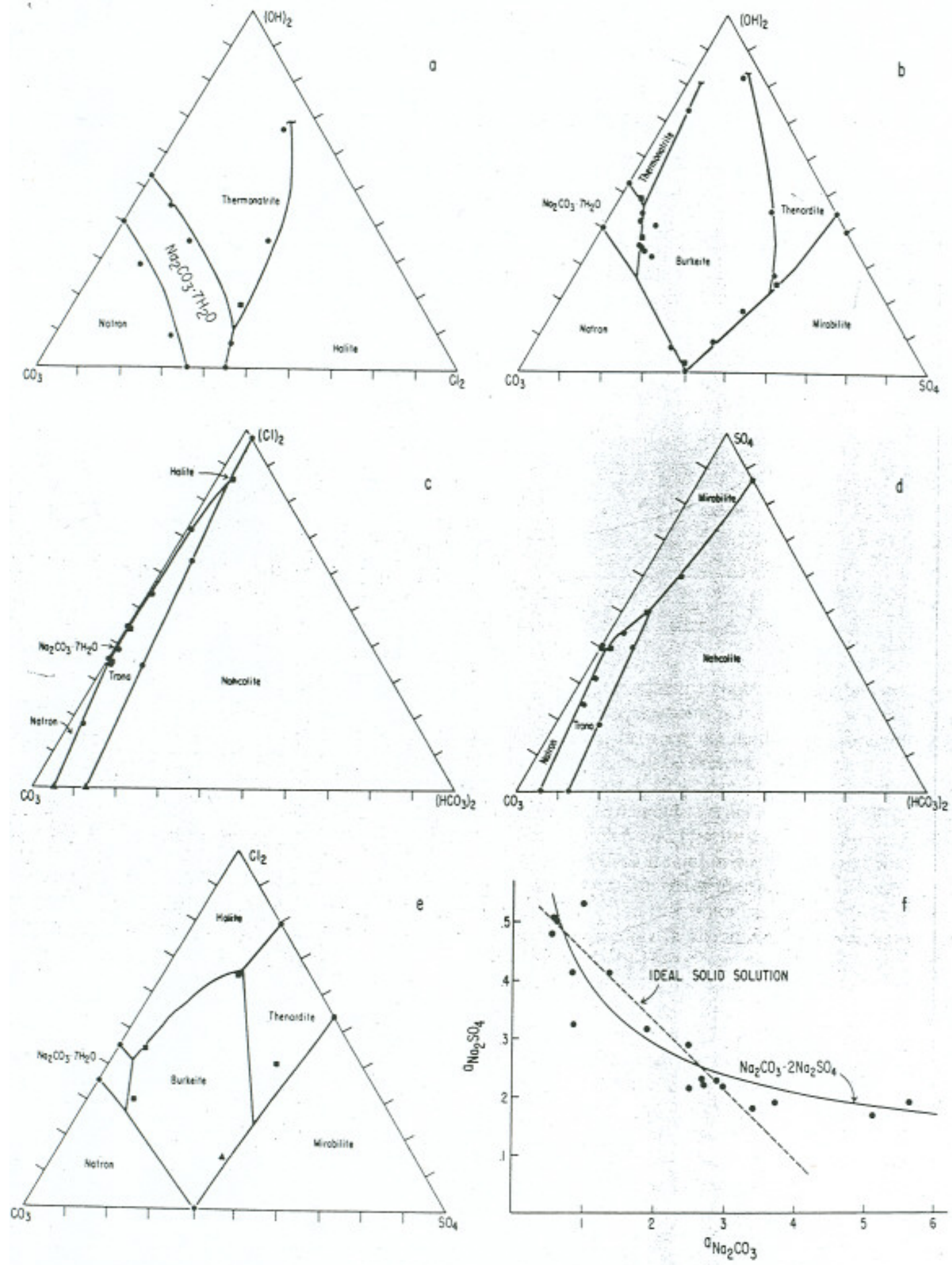

Figure 2. Jänecke projections of minerals solubilities for ternary systems in the $\mathrm{Na}-\mathrm{Cl}$ $\mathrm{SO}_{4}-\mathrm{HCO}_{3}-\mathrm{CO}_{3}-\mathrm{OH}-\mathrm{H}_{2} \mathrm{O}$ system (from Harvie et al. 1984). 


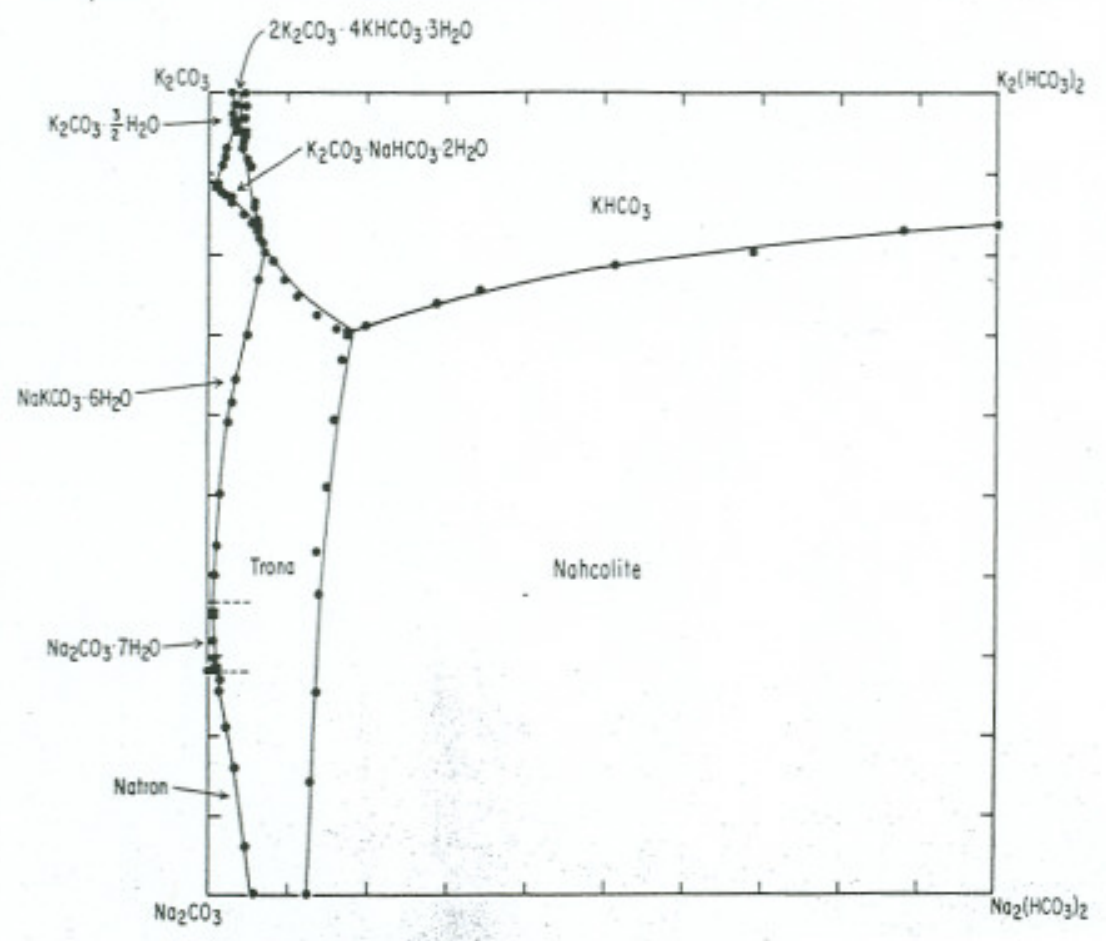

Figure 3. Mineral solubilities in the reciprocal Na-K- $-\mathrm{HCO}_{3}-\mathrm{CO}_{3}$ system (from Harvie et al. 1984).

The simulations for tank 241-AN-107 were initially done with the Pitzer model because of its accuracy, ease of use in fixing partial pressures, and its availability. The ESP model was then used to check the final model predictions. Both models predict similar final $\mathrm{pH}$ values and precipitated solids.

\section{1-AN-107 Solution Compositions}

The waste tank chemical compositions used in the simulations were taken from the updated tank 241-AN-107 core sample analytical results ${ }^{(13)}$. In the case of the upper segments, the analytical results for supernatant segments 1,9 , and 16 were averaged. For the lower segments the salt cake interstitial liquid data for segment 20 were used since this segment had the lowest $\mathrm{pH}, 11.0$, and was considered most likely to be influenced by the introduction of any acidic components. The analytical results in $\mathrm{mg} / \mathrm{l}$ were converted to units of molality (moles $/ \mathrm{Kg} \mathrm{H}_{2} \mathrm{O}$ ) for use in the model simulations (see Table 1). In the case of the upper segments it was necessary to adjust the reported $\mathrm{Na}$ concentrations to achieve charge balance (i.e., $9.9 \mathrm{~m}$ analytical to $10.3 \mathrm{~m}$ ). For the lower segment, there was an analytical excess of cations over anions. Hence, the unreactive component $\mathrm{Cl}$ was increased to achieve the correct ionic strength and obtain charge balance. Besides the constituents shown in Table 1, tank 241-AN-107 also contains significant concentrations of organic chelates (total concentration $\sim 0.5 \mathrm{~m}$ ). The majority of the organic carbon is present as low molecular weight organics, formate and glycolate. Formate and glycolate are not included in the thermodynamic data base for the Pitzer model. However, formate 
and glycolate do not undergo acid/base reactions above $\mathrm{pH} 4$ (pKa values range from 3.8 to 3.9 depending upon ionic strength). Hence these organics will not participate in the acid/base reactions important to this study.

Table 1. Input chemical compositions of upper and lower segments of tank 241-AN-107. All concentrations are reported in units of molality. The notation (CB) indicates the concentration of the component was adjusted to achieve charge balance.

\begin{tabular}{|l|l|l|}
\hline \multicolumn{1}{|c|}{ Component } & \multicolumn{1}{c|}{$\begin{array}{c}\text { Concentration } \\
\text { (upper segment) }\end{array}$} & \multicolumn{1}{c|}{$\begin{array}{c}\text { Concentration } \\
\text { (lower segment) }\end{array}$} \\
\hline $\mathrm{Na}$ & $10.3(\mathrm{CB})$ & 8.24 \\
\hline $\mathrm{NO}_{3}$ & 4.04 & 3.11 \\
\hline $\mathrm{NO}_{2}$ & 1.44 & 1.34 \\
\hline $\mathrm{Al}_{(\mathrm{OH})_{4}}$ & 0.046 & 0.0043 \\
\hline $\mathrm{SO}_{4}$ & 0.023 & 0.074 \\
\hline $\mathrm{PO}_{4}$ & 0.023 & 0.019 \\
\hline $\mathrm{Cl}$ & 0.046 & $0.53(\mathrm{CB})$ \\
\hline $\mathrm{CO}$ & 1.51 & 1.51 \\
\hline $\mathrm{OH}$ & 1.58 & $\sim 0.001(\mathrm{pH} 11)$ \\
\hline
\end{tabular}

\section{Results and Discussion}

Two sets of simulations were performed. The first set of simulations were performed by incrementally adding increasing masses of $\mathrm{CO}_{2}(\mathrm{~g})$ to the solution compositions shown in Table 1 until equilibrium with atmospheric $\mathrm{CO}_{2}(\mathrm{~g})$ was achieved (i.e., $\mathrm{pCO}_{2}=10^{-3.5} \mathrm{~atm}$ ). These simulations provide information on the overall evolution of the supernatants as atmospheric gases infiltrate the tank The second set of simulations were performed by incrementally adding increasing concentrations of $\mathrm{HNO}_{3}$ to the upper segment concentrations shown in Table 1. These simulations provide information on the overall acid buffering capacity of the supernatants.

The changes in carbonate concentration as a function of added $\mathrm{CO}_{2}$ are shown in Figure 4. The results follow the expected trends. In the upper segments, the introduction of atmospheric $\mathrm{CO}_{2}$ results in a net neutralization of the excess $\mathrm{NaOH}$ and the formation of aqueous $\mathrm{Na}_{2} \mathrm{CO}_{3}$, i.e. reaction (1),

(1) $\mathrm{CO}_{2}(\mathrm{~g})+2 \mathrm{NaOH}=\mathrm{Na}_{2} \mathrm{CO}_{3}($ aq $)+\mathrm{H}_{2} \mathrm{O}$.

The aqueous carbonate concentration increases in solution almost, but not quite, to equilibrium with natron $\left(\mathrm{Na}_{2} \mathrm{CO}_{3} \cdot 10 \mathrm{H}_{2} \mathrm{O}\right)$. At this point the aluminum and some carbonate precipitates as dawsonite $\left(\mathrm{NaAlCO}_{3}(\mathrm{OH})_{2}\right)$. Continued introduction of $\mathrm{CO}_{2}$ results in the precipitation of trona via reaction (2),

(2) $\mathrm{CO}_{2}(\mathrm{~g})+\mathrm{NaOH}+\mathrm{Na}_{2} \mathrm{CO}_{3}+2 \mathrm{H}_{2} \mathrm{O}=\mathrm{Na}_{2} \mathrm{CO}_{3} \cdot \mathrm{NaHCO}_{3} \cdot 2 \mathrm{H}_{2} \mathrm{O}$ (trona) 
Trona then continues to precipitate until equilibrium is reached with atmospheric $\mathrm{CO}_{2}$. The final predicted solid phases are trona and dawsonite.

In the case of the lower segment, the initial solutions are predicted to be in equilibrium with dawsonite. Introduction of $\mathrm{CO}_{2}$ then precipitates a small amount of trona before equilibrating with the atmosphere.

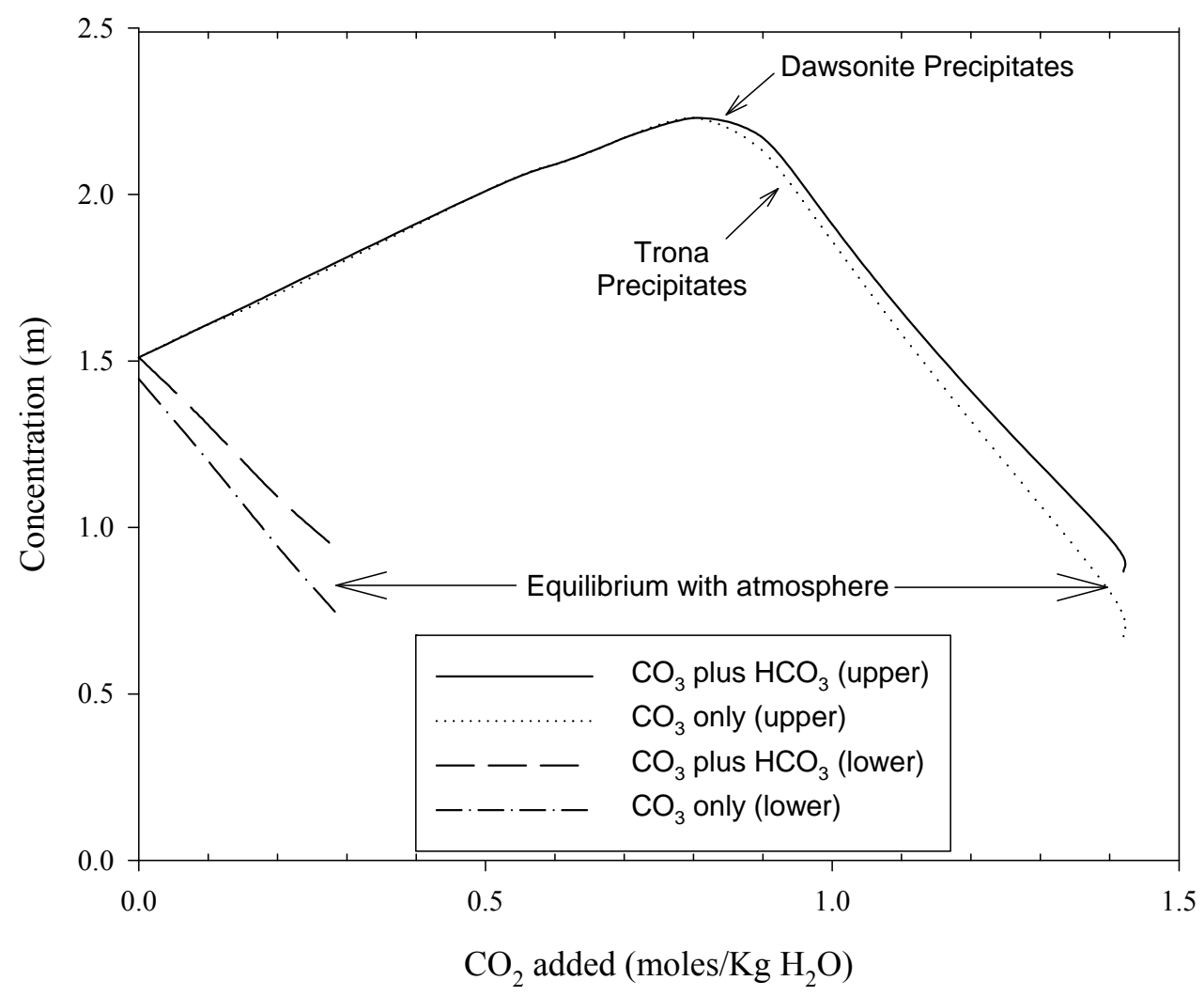

Figure 4. Calculated changes in aqueous carbonate concentration in both the upper and lower segments of tank 241-AN-107 using the Pitzer model.

The calculated changes in $\mathrm{pH}$ values as a result of $\mathrm{CO}_{2}$ additions, Figure 5, reflect the changes in predicted hydroxide and carbonate concentration. In the upper segments, the introduction of $\mathrm{CO}_{2}$ results in a gradual decrease in the $\mathrm{pH}$ as the excess $\mathrm{NaOH}$ is neutralized. Once most of the $\mathrm{NaOH}$ is neutralized the $\mathrm{pH}$ decreases rapidly owing to the lack of buffering capacity until the aqueous solution begins to form significant concentrations of bicarbonate $\left(\mathrm{HCO}_{3}{ }^{-}\right)$which, along with the formation of trona, buffers the changes in $\mathrm{pH}$. In the lower segment there is little excess $\mathrm{NaOH}$ and the changes in $\mathrm{pH}$ are initially buffered by the formation of bicarbonate and trona. 
The final calculated $\mathrm{pH}$ values using the Pitzer model are 10.26 for the upper segment and 10.24 for the lower segment. The standard ESP model gives similar results except for the mass of $\mathrm{CO}_{2}$ required for neutralization. For the upper segment the ESP model predicts the formation of the same solid phases as the Pitzer model (dawsonite and trona) and a similar final $\mathrm{pH}$ (10.08). However, the ESP model predicts that the neutralization of the upper segment will require only 1.1 moles $\mathrm{CO}_{2} / \mathrm{Kg} \mathrm{H}_{2} \mathrm{O}$ while the Pitzer model predicts 1.4 moles $\mathrm{CO}_{2} / \mathrm{Kg} \mathrm{H}_{2} \mathrm{O}$. Since less $\mathrm{CO}_{2}$ is required to achieve equilibrium, the ESP model also predicts less trona formation and hence a higher carbonate concentration in solution. The results are similar for the lower segment. The ESP model predicts a similar final $\mathrm{pH}$ (10.03) to the Pitzer model (10.24) but less introduced $\mathrm{CO}_{2}$ to achieve equilibrium $\left(0.11 \mathrm{moles} / \mathrm{Kg} \mathrm{H}_{2} \mathrm{O}\right.$ versus $\left.0.28 \mathrm{moles} / \mathrm{Kg} \mathrm{H}_{2} \mathrm{O}\right)$. ESP predicts final equilibrium with dawsonite, but not trona in the lower segment.

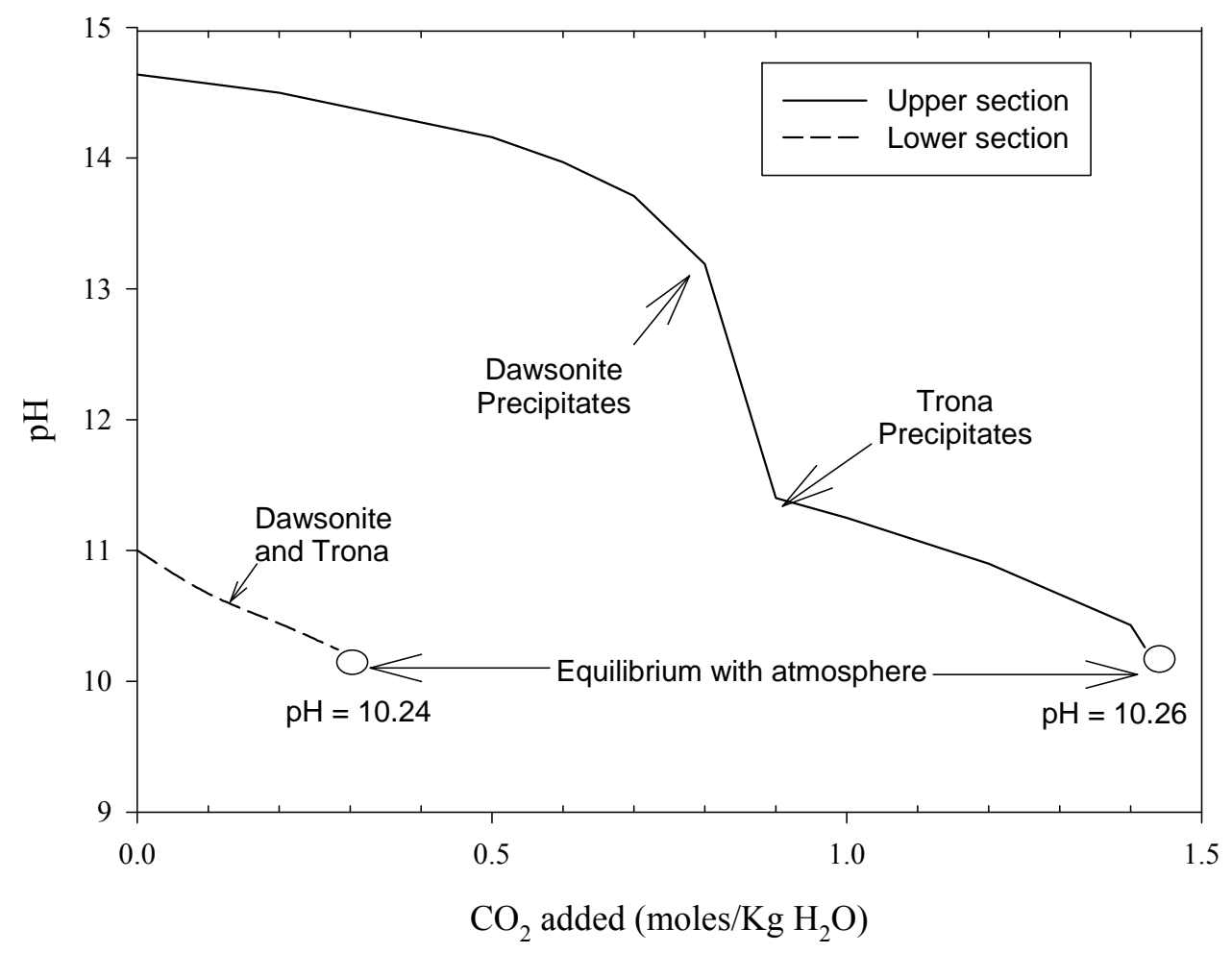

Figure 5. Calculated $\mathrm{pH}$ values for the upper and lower segments of tank 241-AN-107 using the Pitzer model.

The calculations shown above yield information on the expected changes in $\mathrm{pH}$ that could occur as $\mathrm{CO}_{2}$ infiltrates the supernatants. However these calculations do not yield direct information on the stability of these $\mathrm{pH}$ values due to acid additions from organic degradation reactions or other processes. In this regard, the calculated $\mathrm{pH}$ values for the 
upper section of tank 241-AN-107 are shown in Figure 6 as a function of added nitric acid. The $\mathrm{pH}$ is initially high owing to the high $\mathrm{NaOH}$ concentration. As more and more acid is added to the system the $\mathrm{pH}$ gradually decreases until the free $\mathrm{OH}$ is effectively consumed. The $\mathrm{pH}$ then drops rapidly until trona precipitates and the solution equilibrates with the atmosphere $(\mathrm{pH} 10.25)$. Further additions of acid cause $\mathrm{CO}_{2}$ to outgas ( $\mathrm{pCO}_{2}$ maintained at $\left.10^{-3.5} \mathrm{~atm}\right)$, trona to dissolve, and the $\mathrm{pH}$ to remain essentially constant. The reason for the high buffering capacity can be seen from the dissolution reaction for trona in equilibrium with $\mathrm{CO}_{2}(\mathrm{~g})$, reaction (3),

(3) $\mathrm{Na}_{2} \mathrm{CO}_{3} \cdot \mathrm{NaHCO}_{3} \cdot 2 \mathrm{H}_{2} \mathrm{O}$ (trona) $+3 \mathrm{H}^{+}=3 \mathrm{Na}^{+}+2 \mathrm{CO}_{2}(\mathrm{~g})+4 \mathrm{H}_{2} \mathrm{O}$.

At fixed $\mathrm{pCO}_{2}$, the $\mathrm{pH}$ is dependent only upon the concentration of $\mathrm{Na}+$ which remains relatively constant. Reaction (3) then buffers the $\mathrm{pH}$ until essentially all of the carbonate is removed from solution. The $\mathrm{pH}$ then drops rapidly owing to the loss of buffering capacity.

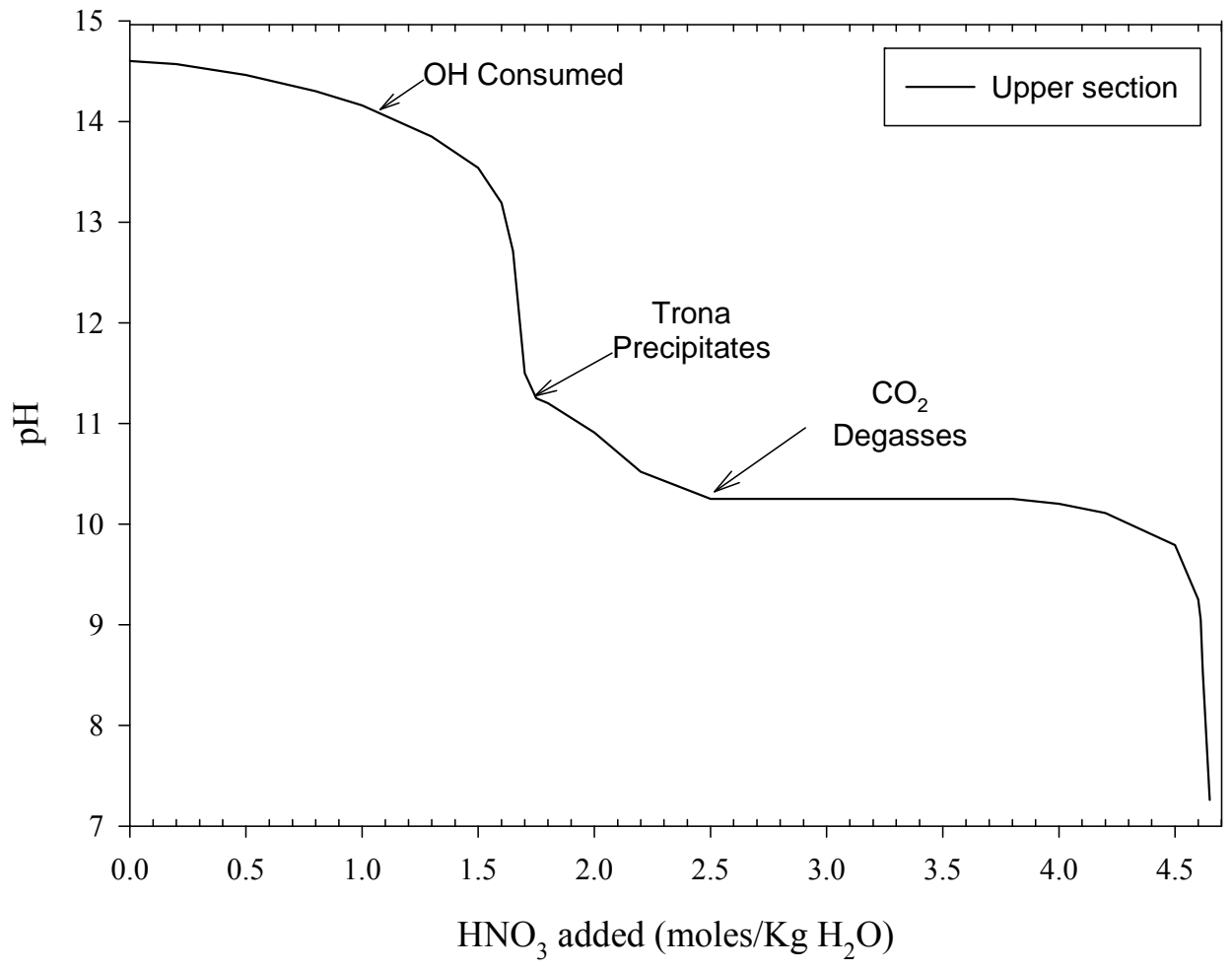

Figure 6. Predicted changes in $\mathrm{pH}$ as the result of acid additions to the upper segments of tank 241-AN-107 using the Pitzer model. 


\section{Summary}

Thermodynamic modeling simulations of the neutralization of the supernatants in tank 241-AN-107 by atmospheric $\mathrm{CO}_{2}$ predict the initial formation of $\mathrm{Na}_{2} \mathrm{CO}_{3}(\mathrm{aq})$ in the upper supernatant segments followed by the precipitation of dawsonite and trona which buffer the final $\mathrm{pH}$ values. In the lower salt cake segment the interstitial liquid solution is initially much closer to equilibrium with the atmosphere and buffered by the carbonate/bicarbonate equilibrium. The final calculated $\mathrm{pH}$ values are similar for the both the upper and lower segments and similar between the Pitzer and ESP models (i.e. upper segment 10.26 (Pitzer), 10.08 (ESP); lower segment 10.24 (Pitzer), 10.03 (ESP)), overall $10.1 \pm 0.2$. The differences between the models appear to be related to different equilibrium constants for trona formation $(\Delta \log \mathrm{K} \sim 0.05)$ and differences in activity coefficients. The final calculated $\mathrm{pH}$ values are expected to be extremely stable with respect to possible acid additions since they are buffered by the high carbonate concentration and the presence of the solid phase trona.

Finally it should be noted that measurement of $\mathrm{pH}$ in concentrated brines is complicated by liquid junction potentials, unknown single ion activities, and different calibration

procedures ${ }^{14}$. Hence measurement of $\mathrm{pH}$ within the estimated modeling accuracy reported here ( \pm 0.2 units) could be quite challenging for these concentrated electrolytes.

\section{Acknowledgements}

The author would like to thank Don Geneisse (COGEMA) for performing the simulations using the standard ESP model.

\section{References}

1. Felmy, A.R. (1995). "GMIN: A Computerized Chemical Equilibrium Model Based Upon a Constrained Minimization of the Gibbs Free Energy." Chapter 18. In: Soil Science Society of America Special Publication 42:377-407.

2. Sanders, S, R. Young and A.R. Felmy (2001). "Inclusion of Pitzer Equations in the ESP Computer Model (Beta Version)." Tanks Focus Area Milestone Report B.3-1 (September 2001).

3. Felmy, A.R., M. Mason, O. Qafoku, and D.A. Dixon. (2003). "Development of Accurate Chemical Equilibrium Models for the Hanford Waste Tanks: The System Na$\mathrm{Ca}-\mathrm{Sr}-\mathrm{OH}-\mathrm{CO}_{3}-\mathrm{NO}_{3}$-EDTA-HEDTA- $\mathrm{H}_{2} \mathrm{O}$ from 25 to $75{ }^{\circ} \mathrm{C}$." ACS Environmental Management Science Program Symposium 2003.

4. Felmy, A.R., J.R. Rustad, M.J. Mason, and R. de la Bretonne. (1994). "A Chemical Model for the Major Electrolyte Components of the Hanford Waste Tanks." Westinghouse Hanford Co. Report No. TWRS-PP-94-090. 
5. Felmy, A.R., and J.H. Weare. (1986). "The Prediction of Borate Mineral Equilibria in Natural Waters: Application to Searles Lake, California." Geochimica. Cosmochimica Acta 50:2771-2783.

6. Rapko, B.M., I.E. Burgeson, H. Cho, J. Deschane, A.R. Felmy, E Jenson, B.K. McNamara, A.P. Poloski, L. Snow, and G.T. MacLean. (2003). "Mixing of WTP Process Solutions." WTP-RPT-080, Rev 0. Prepared for Bechtel National Inc. by Battelle Pacific Northwest Division.

7. Felmy, A.R. and G.T. MacLean (FFS). (2002). "Thermodynamic Modeling of AZ-101 Slurry Leaching.” PNWD-3289, WTP-RPT-067 Rev 0, Final Report. Prepared for Bechtel National Inc. by Battelle Pacific Northwest Division.

8. Felmy, A.R. and G.T. MacLean. (2001). "Development of an Enhanced Thermodynamic Database for the Pitzer Model in ESP: The Fluoride and Phosphate Components.” WTP-RPT-018 Rev. 0. Bechtel National, Inc., Richland, WA.

9. Felmy, A.R. (2000). “Thermodynamic Modeling of Sr/TRU Removal." PNWD-3044, BNFL-RPT-037 Rev 0. Bechtel National, Inc., Richland, WA.

10. Sterner, S.M., A.R. Felmy, P.K. Melethiel, M.J. Mason, and J.R. Rustad. (1996).

"Extension of the ESP Model to High Base and High Aluminate Concentration." Letter Report to the Westinghouse Hanford Company, Richland, WA, July 1996.

11. Sterner, S.M., J.R. Rustad, and A.R. Felmy. (1996). "The Hanford Thermochemical Databank: v 1.00 with Parameters for the ESP and Pitzer Models." Letter Report to the Westinghouse Hanford Company, Richland, WA, September 1996.

12. Rapko, B.M., D.L. Blanchard, N.G. Colton, A.R. Felmy, J. Liu, and G.J. Lumetta. (1996). "The Chemistry of Sludge Washing and Caustic Leaching Processes for Selected Hanford Tank Wastes.” PNNL-11089. The Pacific Northwest National Laboratory, Richland, WA, March 1996.

13. Letter, H.L. Baker to N.W. Kirch, CH2MHILL, "Update Tank 241-AN-107 Fiscal Year 2003 Core Sample Analytical Results for the Final Report", 7S120-HLB-03-001, dated October 6, 2003.

14. Rai, D., A.R. Felmy, S.P. Juracich, and L. Rao (1994). "Estimating the Hydrogen Ion Concentration in Concentrated $\mathrm{NaCl}$ and $\mathrm{Na}_{2} \mathrm{SO}_{4}$ Electrolytes". PNL-9992, Pacific Northwest National Laboratory., Richland Washington. 